\title{
Chagas Disease: Criteria of Cure and Prognosis
}

\author{
Eliane Dias Gontijo/ ${ }^{+}$, Lúcia MC Galvão*, Silvana Eloi-Santos**
}

\begin{abstract}
Departamento de Medicina Preventiva e Social *Departamento de Parasitologia, ICB,UFMG **Departamento de Propedêutica Complementar, Faculdade de Medicina, UFMG, Caixa Postal 340, 30130-100 Belo Horizonte, MG, Brasil
\end{abstract}

Key words: Chagas disease - prognosis - cure

Therapeutic protocols for treating the acute and recent-chronic phases of Chagas disease were unanimously agreed upon by participants of the Symposium on the Specific Treatment of Chagas Disease n 1985. However, long-term clinical trials among patients treated (cured and uncured) for the indeterminate-chronic and initial-cardiac disease forms were recommended to better evaluate the curative action of drugs and to study the clinical evolution of the disease. Clinical trials among these groups of patients were published because studies reported low efficacy of benznidazole in chronic disease (Ferreira 1970, Cançado 1980) while the evaluation of cure was defined as negative parasitologic and serologic test results (Cançado \& Brener 1979). A decade later, specialists met in Brasília under the auspices of the Chagas Disease Control Program of FNS/MS. Those present were concerned about doctors abandoning the specific medication as well as the scarcity of studies on the impact of treatment in the evolution of the disease among untreated and treated patients. Therefore, the 1985 recommendations were reaffirmed.

Today, the proposal of this International Symposium of Chagas Disease to discuss the evolution of knowledge regarding chronic-phase treatment is as timely and relevant as ever.

Regarding the role of the parasite in maintaining the inflammatory process in the chronic phase, recent studies by Kalil et al. (1993) and Higushi (1995) confirm the historic studies of Chagas and Torres and the results of experimental research by Segura et al. (1994) and Andrade et al. (1991). The latter has brought new hope to clinicians because they reported the interruption of the progression of lesions in treated mice, and verified the effect of benznidazole in the regression of myocardial

\footnotetext{
${ }^{+}$Corresponding author. Fax: +55-31-248.9808. E-mail: egontijo@medicina.ufmg.br

Received 9 June 1999

Accepted 9 August 1999
}

inflammatory lesions and in skeletal muscle of chronically infected animals that presented parasitologic cure even though serologic tests were positive.

Even though studies of Macedo and Silveira (1987) and Manzullo et al. (1982) reported no observed differences in the clinical evolution of treated patients who had the indeterminate form of chronic disease, in the 1990s, some investigations have reported the lack of reliable parameters to determine treatment efficacy in the chronic form, which could be responsible for low levels of cure and calls into question the real benefit of treatment. Viotti et al. (1994) followed for an average of eight years, 131 chronic chagasic patients treated with benznidazole and 70 untreated subjects with an average age of less than 50 years. They reported that the treated subjects, independent of negative serologic or parasitologic results, presented fewer alterations in electrocardiograms (4.2\%) compared to the untreated patients $(30 \%)$, and a lower incidence of changes in the clinical stage $(2.1 \%$ vs 17\%). In Brazil, Fragata Filho et al. (1995) conducted a retrospective study that found that among $61 \%$ of subjects with negative xenodiagnosis, only $7 \%$ of treated patients (both cured and uncured) experienced worsened clinical states opposed to $14.3 \%$ of the placebo group, after seven years of follow-up. In 1997, Coura et al. (1997). Treated 26 chronic chagasic patients who had at least two positive results out of three xenodiagnosis tests and verified that after one year, only $1.8 \%$ continued to have positive xenodiagnosis even though serologic tests remained positive.

In 1984, Krettli et al. observed that treated chronic patients had persistently positive serologic tests for long periods of time although lytic antibodies, which recognize epitopes on the surface of living trypomastigotes disappeared early, indicating the absence of active infection. Earlier studies reported the possibility that immune memory (Cerisola et al. 1972) was responsible for persistently positive serologic tests while parasitemia was negative. Viotti (1994) reported that besides the immune memory, pauciparasitemia, low sensitiv- 
ity of xenodiagnosis and absence of short- and mid-term indicators of improved clinical state all contribute to the difficulty of evaluating etiologic treatment.

The role of the strain factor in failed treatment and even disparities in the success of treatment by were demonstrated in 1997 by Toledo et al. who verified different susceptibility levels to treatment according to the $T$. cruzi strain. Ten strains were considered sensitive (61-100\% cure), one partially sensitive (50\% cure) and seven resistant (40\% cure). In addition, the authors reported that benznidazole totally eliminated inflammatory lesions in skeletal muscle and partially eliminated heart lesions in cured rats and even treated, uncured rats experienced a reduction in lesions.

There is consensus that adverse side effects occur in $30 \%$ of patients receiving benznidazole, but in general the side effects do not justify cessation of treatment. The alleged carcinogenic effect has been thoroughly discredited by researchers with well-known clinical experience in the management of chagasic patients.

The disparity in the trypanocidal action of available drugs as well as their negative side effects have prompted a search for new compounds to treat Chagas disease. Nitromidasolics, like metronidazol, and antifungal azolic derivatives, like ketoconazol, have been studied in vitro and in animal models but their efficacy has not been demonstrated in humans. Some authors have raised the possibility of using allopurinol and itraconazole but Rassi et al. (1996) conducted a randomized doubleblind study in 35 patients and concluded that a daily dose of $900 \mathrm{mg}$ of allopurinol was ineffective, having results similar to those of a placebo. Recently, Urbina et al. (1998) investigated the antiproliferative effect of a new antifungal triazole compound and found that it was better than ketoconazole or itraconazole. In a murine model of chronic Chagas disease, the drug was more effective than ketoconazole, providing 75 to $85 \%$ protection from death, with 60 to $75 \%$ parasitologic cures in the surviving animals, while no parasitologic cures were observed with ketoconazole.

The search continues for new compounds against $T$. cruzi that have low toxicity and increased efficacy during the chronic phase. Furthermore, there is a lack of a reliable technique to evaluate cure. Therefore, identifying an antigen that can fulfill the role of evaluating the efficacy of Chagas disease treatment is of the utmost importance. Criteria in treated patients are problematic due to the absence of routine methods to discriminate between those who have been cured and those who have not. Indirect parasitologic tests like xenodiagnosis and hemoculture detect circulating para- sites in 50-70\% of cases (Cerisola et al. 1972, Castro et al. 1983, Chiari et al. 1989, Galvão et al. 1993, Luz et al. 1994). Conventional serology (CS) tests detect antibodies directed against internal or surface components of intact $T$. cruzi or its extracts. Such tests include indirect immunofluorescence, indirect hemagglutination and ELISA, all of which are sufficiently sensitive while having a low percentage of false positives, which normally occur in sera of individuals infected with Leishmania sp. e T. rangeli (Araújo 1986, Chiller et al. 1990). Nevertheless, evaluation of treated chagasic patients presents a certain degree of difficulty since CS remain positive for many years post-treatment in a large percentage of patients, including those who have repeatedly negative parasitologic results (Galvão et al. 1993). CS used to monitor cure (Cançado 1981) slowly and progressively become negative in a small number of treated patients (Krettli et al. 1984, Galvão et al. 1993). Antibodies present in the sera of chagasic patients induce lysis in trypomastigote forms in the presence of a complement (lytic antibodies), indicating the presence of active infection - CoML (Krettli \& Brener 1982). Following specific treatment, lytic antibodies disappear from the sera of some patients while $\mathrm{CS}$ remains positive. This tendency has created new perspectives regarding the evaluation of cure in chagasic patients and shows clear discordance between CS antibodies and lytic antibodies in both human patients and experimental animals, the former being classified as dissociated (Krettli et al. 1982). In 82 chronic patients, $9 \%$ had negative results in all tests and $26 \%$ had persistently negative CoML and hemoculture tests even though CS remained positive, confirming the suspicion that dissociated patients were in fact free of infection. Therefore, the absence of lytic antibodies as measured by repeatedly negative CoML tests post-treatment indicates cure and is a promising result that increases the possibility of detecting successful treatment (Galvão et al. 1993).

Several T. cruzi antigens have been used in ELISA and Western Blot tests to substitute living parasites in the evaluation of cure among chagasic patients who have received specific treatment. The soluble excretory antigens of supernatant trypomastigotes in cell culture (Krautz et al. 1994) as well as GP57/51, purified cystein proteinase of epimastigote forms (Murta et al. 1990) are capable of identifying $70 \%$ of the dissociated treated patients (Gazzinelli et al. 1993). T. cruzi antigens like the F2 fraction glycoconjugate (Almeida et al. 1993 ) and the $24 \mathrm{kDa}-\mathrm{Tc} 24$ recombinant protein (Ouaissi et al. 1992, Taibi et al. 1993, Krautz et al. 1995) as well as the new approach of CoML test using flow cytometry (Martins-Filho et al. 1995) 
have been used to detect anti-living trypomastigote antibodies in sera of treated chagasic patients and have opened new perspectives for evaluating cure.

Another promising tool is polymerase chain reaction (PCR), which has been used to detect $T$. cruzi in the blood of chronic chagasic patients. Initial data reveal positive PCR results in $83-100 \%$ of patients (Ávila et al. 1993, Brito et al. 1995, Gomes et al. 1998). Recently, a strong correlation was reported between positive PCR and CoML results among chagasic patients, suggesting that PCR could be effective in evaluating parasitologic cure in patients who received specific treatment (Gomes et al. 1999).

Besides the use of parasitic and serologic markers to evaluate the effectiveness of trypanocidal drugs, another approach is to identify immunologic markers that are correlated with the presence of the parasite. It is known that $T$. cruzi lives freely within the cytoplasm of infected host cells, interfering with the host immune response, which allows for the establishment of a persistent infection, indicating its success at evading immune clearance.

Immunologic events that occur in Chagas disease are multiple and include diverse effector and regulatory processes that result in a balance between resistance and pathogenesis. Concerning the last mentioned, when a pathologic consequence of the host response develops, severe morbidity secondary to the inflammatory process is seen. Among the implicated immune events, we highlight the involvement of $\mathrm{T}$ cells, which is evidenced by an increase in the proliferative response to parasiterelated stimuli of peripheral $\mathrm{T}$ cells, as well as by immunohistochemical studies in heart tissue that show predominantly $\mathrm{CD} 8+\mathrm{T}$ cell infiltrates and increased HLA class I and II molecule expression in histiocytes and endothelium cells (Reis et al. 1993, Reed 1998). Moreover, immunophenotypic analyses consistently reveal findings of peripheral $T$ cell activation, like the increase in HLA-DR expression consonant to the increase of CD5+ B cell populations (Dutra et al. 1994). Similarly, analyses of cytokines demonstrate type 1 immune response, especially preferential IFN- $\gamma$ production (Gomes 1998).

The hypothesis of active participation of autoimmunity in disease pathogenesis is illustrated by experimental models showing polyclonal activation of $\mathrm{B}$ and $\mathrm{T}$ cells, during the acute phase (Minoprio et al. 1991) and, in human disease, an increase of peripheral CD5+ B cells in chronic infection was observed (Dutra et al. 1994). It has also been demonstrated that infiltrate cells recognize cardiac myosin rather than primary $T$. cruzi antigens in Chagas patient heart tissue (Cunha-Neto et al. 1996). In the other hand, recent studies have revealed a positive association between tissue parasitism and severity of inflammation. Furthermore, some researchers consider parasitization of heart tissue to be both necessary and sufficient to cause tissue damage, thus creating a case against a major autoimmune etiology of the disease (Tarleton et al. 1997).

The long-term effect of etiological treatment on immune response has been investigated in studies in which patients were treated during the acute phase and evaluated years later. It has been reported that, years after treatment and independent of therapy success, a return to normal percentages of $\mathrm{T}$ cells subsets and activated $\mathrm{T}$ cells population is observed (Gomes 1998). Nevertheless, a longitudinal follow up had never been elaborated to elucidate the pathways of immune reorganization.

In conclusion, it is necessary to implement studies that establish the effect of specific therapy on the immune state and on the evolution of Chagas disease. Evaluating cell populations in peripheral blood of patients who received specific chemotherapy is extremely important in determining the role of the parasite and the immune system in the pathological development of Chagas disease. This type of research will allow for the identification of immunologic markers that indicate cure.

Since 1997, researchers from the Chagas Disease Clinic of the Hospital das Clinicas of the Federal University of Minas Gerais, together with those from the Biological Sciences Institute and Fiocruz, have been conducting a prospective study of 140 patients to test the hypothesis that specific treatment can impact the evolution of disease, preventing or retarding the development of defined clinical forms, and that treated chagasic patients differ from untreated ones, independent of cure. In addition to titer serology and hemoculture, lytic antibody test, PCR and parasite antigens were included to improve evaluation of cure. An immunologic evaluation has been made to determine predictive markers of improved clinical outcome. The evaluation focussed on activated cell populations, which could be involved in the immunopathologic mechanisms of disease.

Using flow cytometric immunofluorescence staining for cell surface markers, our preliminary data show a clear tendency of decreased mean and individual percentages of activated T cells (CD3+ HLA DR+) and CD5+ B cells, and an increase in the population of $\mathrm{CD} 3+$ cells as early as 6 months after complete treatment. At the same time, we observed an increase in the expression of CD28 in the CD8 $\mathrm{T}$ cell subpopulations. These findings support the hypothesis that cell activation is correlated to parasite burden. 
Among 129 subjects between the ages of 20 and 50, we conducted a single hemoculture for each patient and found that $51 \%$ of them had positive parasitemia. A year later, during annual checkups, $88 \%$ of treated patients had negative test results.

Whether these results have an impact on preventing disease progression will be determined through extended clinical follow-up. If a positive correlation is observed, we will be able to indicate the use of any of these criteria as predictive indicators of good therapeutic response and improved outcome.

\section{REFERENCES}

Almeida IC, Krautz G.M, Krettli AU, Travassos LR 1993. Glycoconjugates of Trypanosoma cruzi: a 74 $\mathrm{kDa}$ antigen of trypomastigotes specifically reacts with lytic anti-alpha-galactosyl antibodies from patients with chronic Chagas disease. J Clin Lab Anal 7: 307-316.

Andrade SG, Stocker-Guerret S, Pimentel AS et al. 1991. Reversibility of cardiac fibrosis in mice chronically infected with Trypanosoma cruzi under specific chemoterapy. Mem Inst Oswaldo Cruz 86: 187-200.

Araújo FG 1986. Analysis of Trypanosoma cruzi antigens bound by specific antibodies and by antibodies to related tripanosomatids. Infect Immun 53: 179185.

Avila H, Borges-Pereira J, Thiemann O, De Paiva E, Degrave W, Morel CM, Simpson L 1993. Detection of Trypanosoma cruzi in blood specimens of chronic chagasic patients by polymerase chain reaction amplification of kinetoplast minicircle DNA: comparison with serology and xenodiagnosis. J Clin Microbiol 31: 2421-2426.

Britto C, Cardoso MA, Vanni CMM, Hasslocher-Moreno A, Xavier S, Oeleman W, Santoro A, Pimimez C, Morel CM, Wincker P 1995. Polymerase chain reaction detection of Trypanosoma cruzi in human blood samples as a tool for diagnosis and treatment evolution. Parasitology 110: 241-247.

Cançado JR 1980. Forma aguda da doença de Chagas no Brasil. Rev Assoc Med Bras 26: 285-288.

Cançado JR 1981. Standardization of protocols for chemotherapy of Chagas disease, p.15. In Steering Committee on Chemotherapy and Parasitology, World Health Organization, Washington.

Cançado R, Brener Z 1979. Terapêutica. In Z Brener, Z Andrade (eds) Trypanosoma cruzi e Doença de Chagas, Guanabara Koogan, Rio de Janeiro.

Castro CN, Alves MT, Macedo VO 1983. Importância da repetição do xenodiagnóstico para avaliação da parasitemia na fase crônica da doença de Chagas. Rev Soc Bras Med Trop 16: 98-103.

Cerisola JA, Russo MC, Prado C, Yozami LBJ, Rohweder RW 1972. Estudio comparativo de diversos métodos parasitológicos en la enfermedad de Chagas aguda, p. 97-100. In Protozoologia Simposio Internacional sobre Enfermedad de Chagas, Buenos Aires.
Chiari E, Dias JCP, Lana M, Chiari CA 1989. Hemocultures for the parasitological diagnostic of human chronic Chagas disease. Rev Soc Bras Med Trop 22: 19-23.

Chiller TM, Samudio MA, Zoulek G 1990. IgG antibody reactivity with Trypanosoma cruzi and Leishmania antigens in sera of patients with Chagas disease and leishmaniasis. Am J Trop Med Hyg 43: 650656.

Coura J Rodrigues, Abreu Laércio L, Willcox Henry PF, Petana W 1997. Estudo comparativo controlabo com emprego de Benznidazole, Nifurtimox e placedo na forma crônica da doença de Chagas, em uma área de campo com transmissão interrompida. Avaliação preliminar. Rev Soc Bras Med Trop 30: 139-144.

Cunha-Neto E,Coelho VPC, Guilherme L, Fiorelli A, Stolf N, Kalil J 1996. Autoimmunity in Chagas disease: identification of cardiac myosin-B13 Trypanosoma cruzi protein crossreactive $\mathrm{T}$ cell clones in heart lesions of a chronic Chagas' cardiomyopathy patient. J Clin Investigation 98: 1709-1712.

Dutra WO, Martins-Filho O, Cançado JR, Dias JCP, Brener Z, Freeman Jr GL, Colley DG, Gazzinelli G, Parra JC 1994. Activated T and B lymphocytes in peripheral blood of patients with Chagas disease. Int Immunol 6: 499.

Ferreira HO 1970. Treatment of the indetermined form of Chagas disease with nifurtimox and benznidazole. Rev Soc Bras Med Trop 23: 209-211.

Fragata-Filho AA, Boainaim E, Dias da Silva MA 1995. Validade do tratamento etiológico na fase crônica da doença de Chagas com benznidazol. Arq Bras Cardiol 65 (Suppl. I): 71.

Galvão LMC, Nunes RMB, Cançado JR, Brener Z, Krettli AU 1993. Lytic antibodies titre as means of assessing cure after treatment of Chagas disease: a 10 years follow-up study. Trans $R$ Soc Trop Med Hyg. 87: 220-223.

Gazzinelli RT, Galvão LMC, Krautz G, Lima APC, Cançado JR, Scharfstein J, Krettli AU 1993. Use of Trypanosoma cruzi purified glycoprotein (GP57/51) or trypomastigote-shed antigens to assess cure for human Chagas disease. Am J Trop Med Hyg 49: 625635.

Gomes ML, Macedo AM, Vago AR, Pena SDJ, Galvão LMC, Chiari E 1998. Trypanosoma cruzi: Optimization of polymerase chain reaction for detection in human blood. Exp Parasitol 88: 28-33.

Gomes ML, Galvão LMC, Macedo AM, Pena SDJ, Chiari E 1999. Chagas disease diagnosis: Comparative analysis of parasitologic, molecular, and serologic methods. Am J Trop Med Hyg 60: 205-210.

Gomes JAS 1998. Avaliação Imunológica de Pacientes Chagásicos Submetidos a Quimioterapia Durante a Fase Aguda da Infecção Há Aproximadamente 1430 Anos. MSc Thesis, Universidade Federal de Minas Gerais, Belo Horizonte, 99 pp.

Higushi ML 1995. O parasita e a patogenia da forma crônica da doença de Chagas. Arq Bras Cardiol 64: 251-254.

Kalil R, Bocchi E, Rosemberg L 1993. Ressonância magnética para avaliação de processo inflamatório 
de miocárdio da doença de Chagas. Rev Soc Cardiol Estado São Paulo 3 (Suppl.): 54.

Krautz GM, Coutinho, MG, Galvão LMC, Cançado JR, Krettli AU 1994. Soluble antigens released by Trypanosoma cruzi trypomastigotes used in ELISA to detect cure in chagasic patients following specific treatment. Rev Soc Bras Med Trop 27: 199-207.

Krautz GM, Galvão LMC, Cançado JR, GuevaraEspinosa A, Ouaissi A, Krettli AU 1995. Use of $24 \mathrm{kDa}$ Trypanosoma cruzi recombinant protein to monitor cure of Chagas disease. J Clin Microbiol 33: 2086-2090.

Krettli AU, Brener Z 1982. Resistence against Trypanosoma cruzi associated to anti-living trypomastigote antibodies. J Immunol 128: 2008-2012.

Krettli AU, Cançado JR, Brener Z 1982. Effect of specific chemotherapy on the levels of lytic antibodies in Chagas disease. Trans $R$ Soc Trop Med Hyg 76: 334-340.

Krettli AU, Cançado JR, Brener Z 1984. Criterion on cure of human Chagas disease after specific chemotherapy: recent advances. Mem Inst Oswaldo Cruz 79: 157-164.

Luz ZMP, Coutinho MG, Cançado JR, Krettli AU 1994. Hemoculture: sensitive technique in the detection of Trypanosoma cruzi in chagasic patients in the chronic phase of Chagas disease. Rev Soc Bras Med Trop 27: 143-148.

Macedo V, Silveira CA 1987. Perpectivas da terapêutica específica da doença de Chagas na forma indeterminada. Rev Soc Bras Medicina Tropical 20 (Suppl. 2) 24-26.

Manzullo EC, Danaidon MA, Libonatti O, Rozlosnik J 1982. Estudio Longitudinal de la Cardiopatia Chagasica Cronica, Fac. Ciencias Medicas, Buenos Aires, $141 \mathrm{pp}$.

Murta ACM, Persechini PM, Souto-Padron T, de Souza W, Guimarães J, Scharfstein J 1990. Structural and functional identification of GP57/51 antigen of Trypanosoma cruzi as a cystein proteinase. Mol Biochem Parasitol 43: 27-46.

Martins-Filho OA, Pereira MES, Carvalho JF, Cançado JR, Brener Z 1995. Flow cytometry, a new approach to detect anti-live trypomastigote antibodies and monitor the efficacy of specific treatment in human Chagas disease. Clin Diag Lab Immunol 2: 569-573.

Ouaissi A, Aguirre T, Plumas-Marty B, Piras M, Schoveck R, Gras-Masse H, Taibi A, Loyens M, Tartar A, Capron A, Piras R 1992. Cloning and sequencing of a $24 \mathrm{kDa}$ Trypanosoma specific antigen released in association with membrane vesicles and defined by monoclonal antibody. Biol Cell 75: 11-17.

Rassi A, Luquetti A 1996. Tratamento específico da doença de Chagas. Métodos laboratoriais específicos. Rev Soc Bras Med Trop 29 (Supl. 2): 63-65.

Reed SG 1998. Immunology of Trypanosoma cruzi infections. Chem Immunol 70: 124-143

Reis DD, Jones EM, Tostes S, Lopes ER, Chapadeiro E, Gazzinelli G, Colley DG, McCurley T 1993. Expression of major histoaompatibility complex antigens and adhesion molecules in hearts of patients with chronic Chagas disease. Am J Trop Med Hyg 49: 192-196.

II Reunião Anual sobre Pesquisa Aplicada em Doença de Chagas. Tratamento específico 1986. Rev Soc Bras Med Trop 19: 102-103.

Segura MA, Molina de Raspi E, Basombrio MA 1994. Reversibility of muscle and heart lesions in chronic, Trypanosoma cruzi infected mice, after late trypanomicidal treatment. Mem Inst Oswaldo Cruz. 89: 213-16.

Taibi A, Plumas-Marty B, Guevara-Espinosa A, Schoneck R, Pessoa H, Loyens M, Piras R, Aguirre T, Gras-Masse H, Bossus M 1993. Trypanosoma cruzi: immunity induced in mice and rats by trypomastigote excretory-secretary antigens and identification of a peptide sequence containing a $\mathrm{T}$ cell epitope with protective activity. J Immunol 151: 2676-2689.

Tarleton RL, Zhang L, Dowons MO 1997. “Autoimmune rejection" of neonatal heart transplants in experimental Chagas disease is a parasite-specific response to infected host tissue. Proc Natl Acad Sci USA 94: 3932-3937.

Toledo MJ, Guilherme AL, Silva JC 1997. Trypanosoma cruzi chemotherapy with benznidazol in mice inoculated with strains from Paraná state and different endemic areas of Brasil. Rev Inst Med Trop São Paulo 39: 283-290.

Urbina JA, Payares G, Contreras LM, Liendo A, Sanoya C, Molina J, Piras M, Piras R, Perez N, Wincker P, Loenberg D 1998. Antiproliferative effects and mechanism of action of SCH 56592 against Trypanosoma (Schizotrypanum) cruzi: in vitro and in vivo studies. Antimicrob Agents Chemother 42: 17711777.

Viotti R, Vigliano C, Armenti H, Segura E 1994. Treatment of chronic Chagas disease with benzonidazole: clinical and serologic evolution of patients with longterm follow-up. Am Heart J 127:151-162. 